\title{
Organic Environments on Saturn's Moon, Titan: Simulating Chemical Reactions and Analyzing Products by FT-ICR and Ion-Trap Mass Spectrometry
}

\author{
Arpad Somogyi, Chu-Ha Oh, and Mark A. Smith \\ Department of Chemistry, University of Arizona, Tucson, Arizona, USA
}

\author{
Jonathan I. Lunine \\ Lunar and Planetary Science Laboratory, University of Arizona, Tucson, Arizona, USA
}

Laboratory simulations have been carried out to model chemical reactions that possibly take place in the stratosphere of Saturn's moon, Titan. The aerosol products of these reactions (tholin samples) have been systematically analyzed by mass spectrometry using electrospray ionization (ESI) and laser desorption (LD). A wide variety of ions with a general formula $\mathrm{C}_{\mathrm{x}} \mathrm{H}_{\mathrm{y}} \mathrm{N}_{\mathrm{z}}$ detected by ultrahigh resolution and accurate mass measurements in a Fourier transform/ion cyclotron resonance (FT-ICR) cell reflect the complexity of these polymeric products, both in chemical compositions and isomeric distributions. As a common feature, however, tandem mass spectral (MS/MS) data and H/D exchange products in the solution phase support the presence of amino and nitrile functionalities in these (highly unsaturated) "tholin" compounds. The present work demonstrates that ESI-MS coupled with FT-ICR is a suitable and "intact" method to analyze tholin components formed under anaerobic conditions; only species with $\mathrm{C}_{\mathrm{x}} \mathrm{H}_{\mathrm{y}} \mathrm{N}_{\mathrm{z}}$ are detected for freshly prepared and harvested samples. However, when intentionally exposed to water, oxygen-containing compounds are unambiguously detected. (J Am Soc Mass Spectrom 2005, 16, 850-859) ( 2005 American Society for Mass Spectrometry

$\mathrm{T}$ Titan, the largest of Saturn's moons, is known to possess a rich organic environment of important relevance to astrobiology, prebiotic earth chemistry, and the origin of life, since the organics have been protected from damaging particles and UV radiation owing to a thick atmosphere. Many small organic compounds have been detected in Titan's upper atmosphere as a result of Voyager [1-8] and subsequent modeling studies $[9,10]$ of the organic and atmospheric haze chemistry are resulting in a refined picture of this complex CHN laboratory. Beginning in 2005, we should have a refined global inventory of low molecular weight organic molecules present in the atmosphere as well as some secondary information regarding higher mass organic aerosols presented to the surface of Titan as a result of the Cassini-Huygens mission [11, 12]. Ongoing laboratory collection of atmospheric gas and aerosol data is of particular interest and importance, especially in the light of the Cassini-Huygens mission. As part of these studies, simulation of chemical reac-

Published online March 30, 2005

Address reprint requests to Dr. M. A. Smith, Department of Chemistry, University of Arizona, Building 41, 1306 E. University St., P.O. Box 210041,

Tucson, AZ, 85721. E-mail: msmith@email.arizona.edu tions in laboratories that are relevant to Titan and the analyses of the products can contribute to a better understanding of the chemical processes that can occur in this remote "chemical laboratory." Critical to such studies are the development of reliable and "intact" analytical methods to analyze the products of these reactions and the chemical composition of Titan organic analogs. The application of ultrahigh resolution Fourier ion cyclotron resonance (FT-ICR) mass spectrometry is particularly important because of resolution and mass range limitation regarding both the Huygens gas chromatograph/mass spectrometer (GC-MS) system as well as the aerosol pyrolysis mass spectrometric measurements. These limitations will leave many questions unanswered regarding the full inventory of organic molecules contributing to both the haze chemistry and, more importantly, the surface organic chemistry following Hughens' descent.

The general components of Titan's atmosphere include $\mathrm{N}_{2}, \mathrm{CH}_{4}, \mathrm{H}_{2}$, and $\mathrm{Ar}$ as well as a suite of lower density hydrocarbons including $\mathrm{HCN}, \mathrm{C}_{2} \mathrm{H}_{2}$ and $\mathrm{C}_{2} \mathrm{H}_{4}$, and higher homologs. There is no evidence for the presence of $\mathrm{O}_{2}$ or $\mathrm{H}_{2} \mathrm{O}$. The lower, "classical greenhouse" type troposphere (with a ca. $4 \mathrm{~km}$ thickness) is dominated by convection and overlaid by a strato- 
sphere. The mid-to-upper troposphere is in radiative equilibrium with some moist convection (liquid $\mathrm{C}_{1}$ and $\mathrm{C}_{2}$ hydrocarbons). Thermal infrared opacity originates from collisions among $\mathrm{CH}_{4}, \mathrm{~N}_{2}$, and $\mathrm{H}_{2}$, while optical opacity is afforded by at least one hydrocarbon aerosol haze layer [13-17]. The stratospheric heating is provided by haze that absorbs ultraviolet (UV) and blue sunlight. Aerosol chemistry, including tholin formation, is driven by photochemistry and energetic particles from Saturn's magnetosphere as well as background $\gamma$ radiation. Tholins, the complex organic precipitates originating from Titan's atmospheric aerosol layers, form the feedstock for a complex organic chemistry at the surface level. The $95 \mathrm{~K}$ surface of Titan is believed to have a mixture of liquid hydrocarbons, water ice and tholin particulate deposition or rainout.

We have been interested in synthesizing, isolating, and characterizing the nonvolatile tholin fraction in our laboratory. Accordingly, experimental simulation of tholin synthesis was carried out under varying conditions and concentrations. In previous papers $[18,19]$, we summarized some of our preliminary results focusing mostly on the astrobiological significance and fluorescent properties. In the present paper, we provide a more detailed discussion of the mass spectral data. We focus here on the analytical chemistry aspects of these studies, such as the importance and necessity of ultrahigh mass resolution, exact mass measurements, $H / D$ exchange, and tandem mass spectrometry (MS/MS) experiments for a more coherent and complex characterization of tholin samples. In addition, initial qualitative results for hydrolysis studies have also been reported. One of our major goals is to define the functional group inventory within tholins to eventually appreciate potential reactivity of Titan surface deposited aerosols. To our best knowledge, we provide here the first detailed mass spectral analysis of laboratory tholin samples and their hydrolysis products.

\section{Experimental}

In a representative tholin preparation, a mixture of $5 \%$ $\mathrm{CH}_{4}$ and $95 \% \mathrm{~N}_{2}$ was exposed to an AC electrical discharge under slow flow $\left(6 \mathrm{~atm} \mathrm{~L} \mathrm{~h}^{-1}\right.$ and at a pressure of $10^{-2}$ bar) at a temperature of $195 \mathrm{~K}$ in a glass reaction vessel. During a typical total gas flow of $8 \mathrm{~mol}$, approximately $220 \mathrm{mg}$ of a red/orange tholin film developed on the walls of the vessel kept at $195 \mathrm{~K}$. Isolation was performed in an oxygen-free, dry glovebox and the samples were stored in an air-free environment until further tested. The calculated carbon-consumption during tholin generation was $\sim 10 \%$ determined from the obtained tholin and the bulk $\mathrm{C}$ elemental abundance (average $\% \mathrm{C}=66$ ). Multiple tholin production runs were repeated with $0.5,2$, and $8 \%$ concentrations of $\mathrm{CH}_{4}$ in $\mathrm{N}_{2}$, under identical experimental conditions.

For mass spectrometric analysis, the samples were dissolved in $\mathrm{CH}_{3} \mathrm{OH}: \mathrm{CH}_{3} \mathrm{CN}$ 1:1 (in a ca. 500-1000 $\mu$ mol concentration range) and analyzed by electrospray ionization (ESI) $[20-24]^{\circ}$ with ${ }^{\circ}$ normal ${ }^{\circ} \mathrm{ESI}^{\circ} \mathrm{con}-$ ditions. ESI is considered to be a "cold" ionization method, which strips molecules from solution predominantly as protonated (or deprotonated) species into the gas phase. In general, no significant fragmentation of the protonated molecules occurs during the ESI process, which makes this ionization technique suitable for analysis of (complex) mixtures. A Finnigan ion-trap (Thermoelectron, San Jose, CA) was used for low resolution, MS/MS, and gas-phase H/D exchange measurements. In the gas-phase $\mathrm{H} / \mathrm{D}$ exchange experiments, $\mathrm{D}_{2} \mathrm{O}$ was introduced into the ion trap and used as the reagent gas (10 s reaction time, 1 to $2 \times 10^{-5}$ torr $\mathrm{D}_{2} \mathrm{O}$ pressure). An IonSpec (Lake Forest, CA) $4.7 \mathrm{~T}$ Fourier transform ion cyclotron resonance (FT-ICR) instrument was used for gasphase H/D exchange experiments, as well as exact mass measurements with different tuning (ion collection) parameters for lower and higher mass ions, respectively. For gas phase H/D exchange experiments, a time window of 10 to $600 \mathrm{~s}$ was used with two different $\mathrm{D}_{2} \mathrm{O}$ pressures applied, $4.5 \times 10^{-9}$ torr and $3.7 \times 10^{-8}$ torr, respectively. The $[\mathrm{M}+\mathrm{H}]^{+}$ions of small peptides, such as triglycine $\left(\mathrm{G}_{3}\right)$ and glycinarginine homologs $\left(G_{n} R\right.$, where $\left.n=1-4\right)$ were used as internal standards for accurate mass measurements. Because these peptides have been dissolved in MeOH: $\mathrm{H}_{2} \mathrm{O}$ 1:1 and it was desirable not to expose our samples to $\mathrm{H}_{2} \mathrm{O}$ for the analyses of "intact" tholin samples, after careful calibrations with these standards, we applied "self-internal" calibrations in subsequent measurements. We have used the following $m / z$ ratios for self-calibration: $138.1081\left(\mathrm{C}_{7} \mathrm{H}_{10} \mathrm{~N}_{3}\right)$, $192.1501\left(\mathrm{C}_{11} \mathrm{H}_{18} \mathrm{~N}_{3}\right)$, and $273.2079\left(\mathrm{C}_{16} \mathrm{H}_{25} \mathrm{~N}_{4}\right)$. For solution phase $\mathrm{H} / \mathrm{D}$ exchange experiments, the samples were dissolved in $\mathrm{CD}_{3} \mathrm{OD}: \mathrm{CH}_{3} \mathrm{CN}$ 1:1 and were run under identical conditions as the regular $(\mathrm{H})$ samples on the FT-ICR instrument. Sustained offresonance irradiation (SORI) with $\mathrm{N}_{2}$ as collision gas was used to perform MS/MS experiments in the FT-ICR cell. For SORI spectra, the precursor ion was used as a calibrant. Methanol was added to the hydrolyzed samples so that the water:methanol ratio was kept at 1:1.

For hydrolysis studies, we prepared four different samples. In each case, $12 \mathrm{mg}$ of tholin was dissolved in $\mathrm{H}_{2} \mathrm{O}$ (Samples $\mathrm{A}$ and $\mathrm{B}$ ) and in $\mathrm{H}_{2} \mathrm{O}$ containing about 1 to $2 \% \mathrm{NH}_{4} \mathrm{OH}$ (Samples $\mathrm{C}$ and $\mathrm{D}$ ). Immediately after making the solutions, the vials were sealed from air. Samples A and C were incubated at room temperature for $5 \mathrm{~h}$, while Samples B and D were heated at $100{ }^{\circ} \mathrm{C}$ for $1 \mathrm{~h}$.

For $^{\circ}$ laser $^{\circ}$ desorption $^{\circ}(\mathrm{LD})^{\circ}[25]^{\circ}$ experiments, $^{\circ} \mathrm{a}^{\circ}$ few microliters of tholin solution used for ESI studies was deposited on the probe plate. After solvent evaporation, a layer of tholin was formed and was exposed to a commercial nitrogen laser $(337 \mathrm{~nm})$ in a Bruker Reflex 


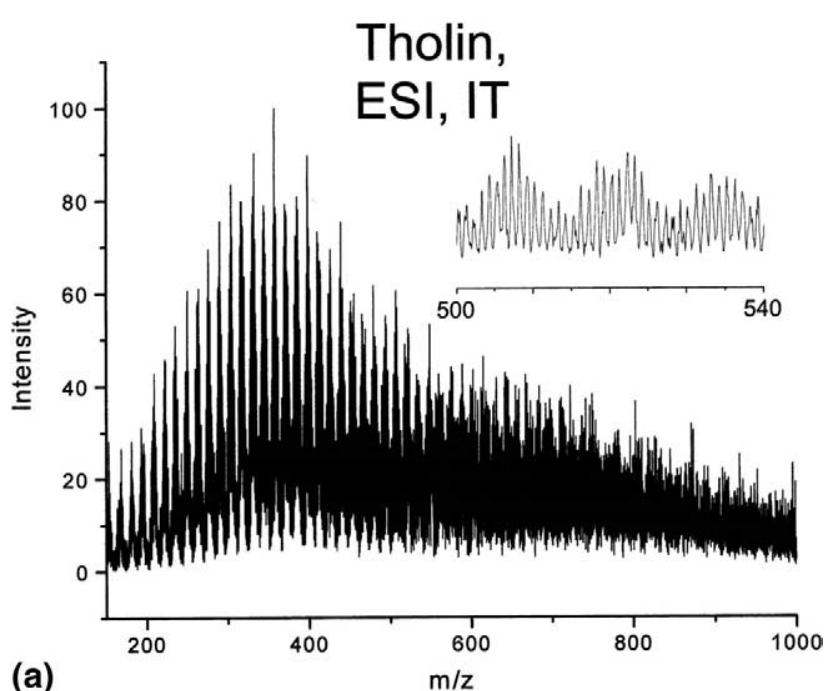

(a)

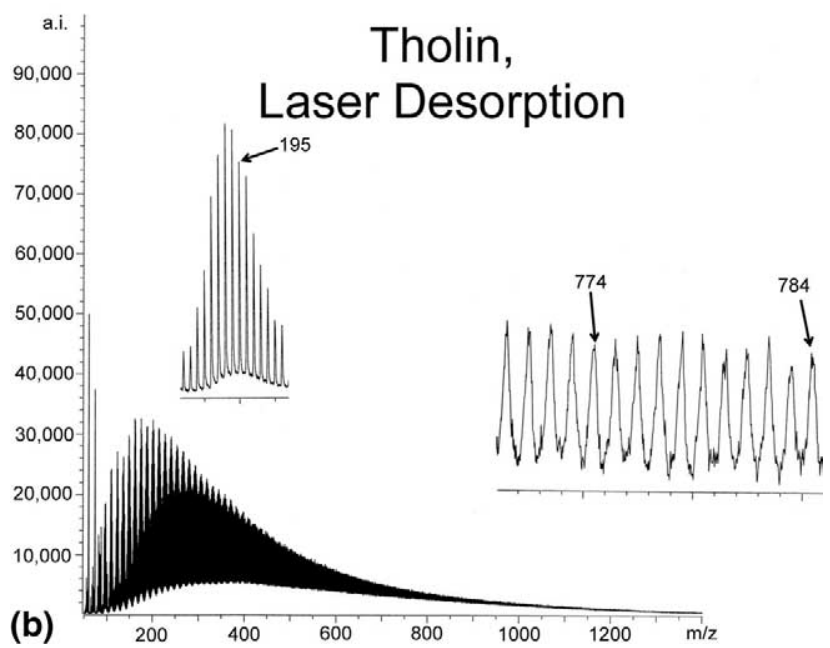

Figure 1. Representative mass spectra of tholin samples obtained by using (a) ESI coupled with an ion trap instrument and (b) laser desorption with a MALDI-TOF instrument. Although different $\mathrm{m} / \mathrm{z}$ regions are shown, both spectra show the polydispersity of tholin polymers.

III MALDI-TOF instrument (Bruker Daltonics, Inc., Billerica, MA).

\section{Results and Discussion}

Figure $^{\circ} 1 \mathrm{a}^{\circ}$ and $^{\circ} \mathrm{b}^{\circ}$ show $^{\circ}$ representative ${ }^{\circ}$ mass $^{\circ}$ spectra obtained ${ }^{\circ}$ for $^{\circ} a^{\circ}$ wider $^{\circ} \mathrm{m} / z$ range ${ }^{\circ}$ by $^{\circ} \mathrm{ESI}^{\circ}{ }^{\circ}{ }^{\circ}\left(\text { Figure }^{\circ} 1 \mathrm{a}\right)^{\circ} \mathrm{a}$ Finnigan ${ }^{\circ}$ ion $^{\circ} \operatorname{trap}^{\circ}(\mathrm{IT})^{\circ}$ instrument $^{\circ}$ and $^{\circ}\left(\text { Figure }^{\circ} 1 \mathrm{~b}\right)^{\circ}$ by laser desorption (LD) on a Bruker Reflex III MALDITOF instrument. A similar spectrum obtained on the IonSpec 4.7 T FT-ICR instrument has been published recently ${ }^{\circ}[18] .{ }^{\circ}$ Figure ${ }^{\circ} 2 a^{\circ}$ and $^{\circ} b^{\circ}$ show $^{\circ}$ ions ${ }^{\circ}$ at ${ }^{\circ}$ lower ${ }^{\circ} \mathrm{m} / \mathrm{z}$ detected in the ion trap (IT) and in the FT-ICR instruments, respectively. Overall, the general features of all spectra are similar. They all show simple and regular patterns in the molecular weight (MW) distribution of the compounds, i.e., regularly spaced clusters separated by 14 mass units $(\mathrm{u})$. The laser desorption spectrum
(Figure $\left.^{\circ} 1 \mathrm{~b}\right)^{\circ}$ clearly $^{\circ}$ shows $^{\circ}$ ions $^{\circ}$ with $^{\circ}$ higher $^{\circ}$ mass $^{\circ}$ to charge ratios (see inset) and implies high polydispersity of the tholin polymers. Previous tholin studies have focused primarily on low molecular weight components $^{\circ}\left(<120^{\circ} \mathrm{u}\right)^{\circ}$ and ${ }^{\circ}$ the ${ }^{\circ}$ mass $^{\circ}$ spectra ${ }^{\circ}$ shown ${ }^{\circ}{ }^{\circ}{ }^{\circ}$ Figure 1 demonstrate the great complexity of laboratory tholins. It should be noted, however, that all laboratory tholin synthesis most likely over-polymerize tholins relative to the bulk aerosol formation and transport processes active in Titan's atmosphere owing to the much greater energy density employed in the laboratory for chemical activation.

Ultrahigh resolution and exact mass measurements using internal standards (see Experimental) in the FTICR cell allowed us to identify compounds with the same nominal mass. For example, in the representative

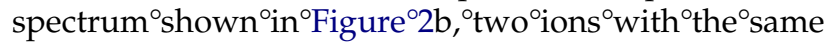
nominal mass $\left(m / z\right.$ 192) are observed: $\mathrm{C}_{9} \mathrm{H}_{14} \mathrm{~N}_{5}$ (measured: $192.1248 \mathrm{u}$, calculated: $192.1249 \mathrm{u})$ and $\mathrm{C}_{11} \mathrm{H}_{18} \mathrm{~N}_{3}$ (measured: 192.1499, calculated: 192.1501). This is valuable information that could not have been obtained exclusively using the "unit" resolution ion trap instru-
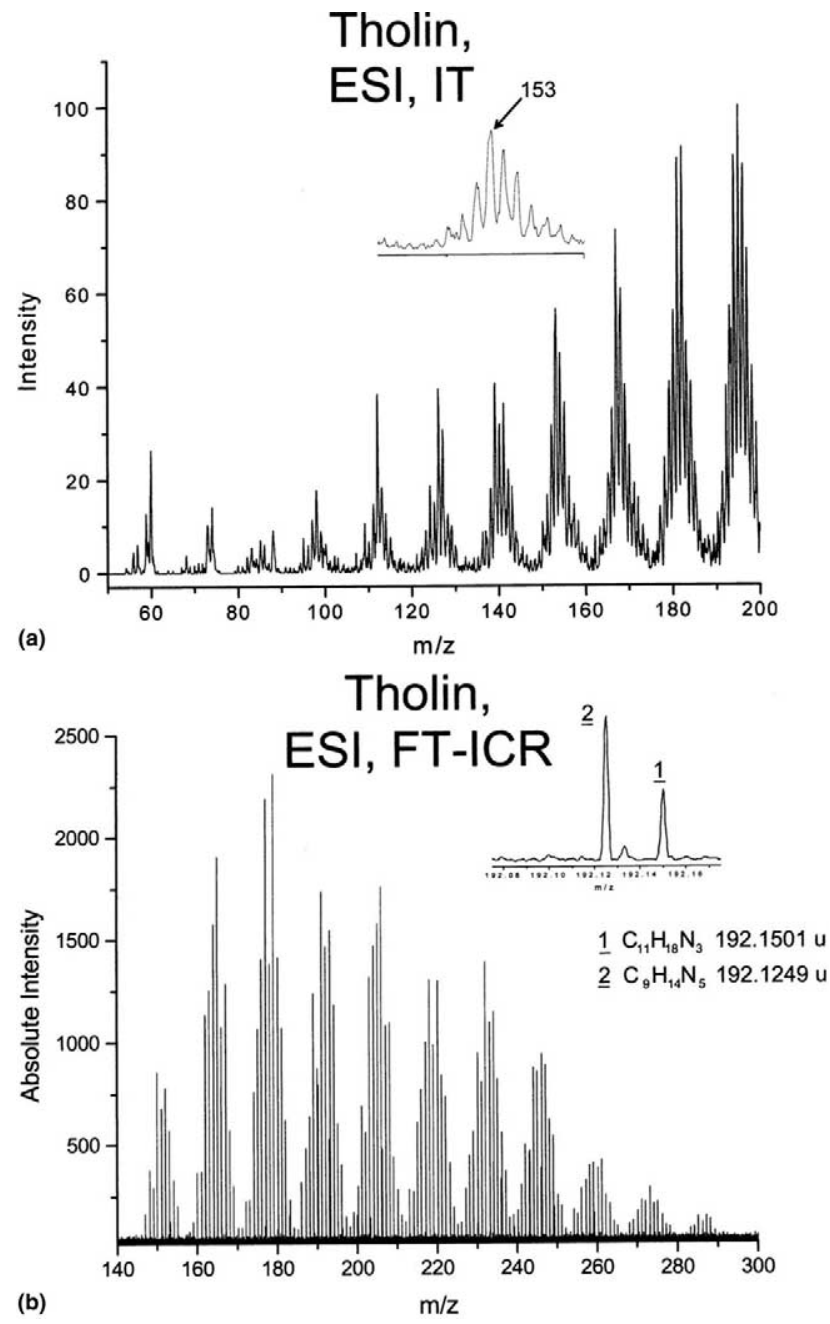

Figure 2. Lower $\mathrm{m} / \mathrm{z}$ region of ESI (a) ion trap and (b) FT-ICR spectra. 
Table 1. The list of masses measured by FT-ICR accurate mass measurements for some lower mass ions. The chemical formula, relative intensity and the $\mathrm{C} / \mathrm{N}$ ratio are also given

\begin{tabular}{cccc}
\hline Measured $m / z$ & Chem. formula & $\begin{array}{c}\text { Relative } \\
\text { intensity }\end{array}$ & C/N ratio \\
\hline \hline 122.0717 & $\mathrm{C}_{6} \mathrm{H}_{8} \mathrm{~N}_{3}$ & 8.4 & 2.00 \\
136.0874 & $\mathrm{C}_{7} \mathrm{H}_{10} \mathrm{~N}_{3}$ & 45.8 & 2.33 \\
150.1031 & $\mathrm{C}_{8} \mathrm{H}_{12} \mathrm{~N}_{3}$ & 39.3 & 2.66 \\
164.1188 & $\mathrm{C}_{9} \mathrm{H}_{14} \mathrm{~N}_{3}$ & 27.0 & 3.00 \\
178.1345 & $\mathrm{C}_{10} \mathrm{H}_{16} \mathrm{~N}_{3}$ & 22.9 & 3.33 \\
192.1499 & $\mathrm{C}_{11} \mathrm{H}_{18} \mathrm{~N}_{3}$ & 18.6 & 3.66 \\
206.1658 & $\mathrm{C}_{12} \mathrm{H}_{20} \mathrm{~N}_{3}$ & 16.1 & 4.00 \\
220.1814 & $\mathrm{C}_{13} \mathrm{H}_{22} \mathrm{~N}_{3}$ & 12.5 & 4.33 \\
234.1973 & $\mathrm{C}_{14} \mathrm{H}_{24} \mathrm{~N}_{3}$ & 8.8 & 4.66 \\
248.2127 & $\mathrm{C}_{15} \mathrm{H}_{26} \mathrm{~N}_{3}$ & 5.9 & 5.00 \\
\hline
\end{tabular}

These ions correspond to neutrals with a general formula $\mathrm{C}_{6} \mathrm{H}_{8}\left(\mathrm{CH}_{2}\right)_{n} \mathrm{~N}_{3}$ ( $n=0-9$, Series 1$)$. Note that for all the corresponding neutral species the degree of unsaturation is 4 .

ment..$^{\circ}\left(\right.$ For $^{\circ}$ the ${ }^{\circ}$ discussion $^{\circ}$ of $^{\circ}$ other $^{\circ}$ peaks $^{\circ}$ in $^{\circ}$ Figure $^{\circ} 2 \mathrm{a}$ and $b$, see below.) Some experimental masses determined by accurate mass measurements for a homologous series of ions of $\mathrm{C}_{6} \mathrm{H}_{8}\left(\mathrm{CH}_{2}\right)_{n} \mathrm{~N}_{3}, n=0-9$, were collected ${ }^{\circ}$ in $^{\circ}$ Table $^{\circ} 1 .^{\circ}$ Note $^{\circ}$ that ${ }^{\circ}$ the ${ }^{\circ}$ corresponding ${ }^{\circ}$ theoretical (calculated) masses agree with the measured ones $^{\circ}$ within $^{\circ} \pm 4^{\circ} \times{ }^{\circ} 10^{-4^{\circ}}$ Da. ${ }^{\circ}$ In $^{\circ}$ Table $^{\circ} 1^{\circ}$ and ${ }^{\circ}$ throughout the paper, we define ions belonging to the same series if they differ from each other by $-\mathrm{CH}_{2}-$ units. In the

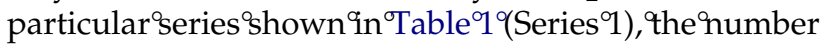
of nitrogens is the same, as well as the degree of unsaturation (4) for the corresponding neutral species. Within a given series, the $\mathrm{C} / \mathrm{N}$ ratio naturally increases with increasing molecular mass (e.g., from 2.00 to 5.00, as $^{\circ}$ shown $^{\circ}$ in $^{\circ}$ Table $\left.^{\circ} 1\right){ }^{\circ}{ }^{\circ}$ The $^{\circ}$ relative ${ }^{\circ}$ intensity ${ }^{\circ}$ data $^{\circ}$ (normalized to an internal standard) show that this particular series has the same characteristic distribution as was ${ }^{\circ}$ illustrated ${ }^{\circ}$ in $^{\circ}$ reference $^{\circ}[18]^{\circ} .^{\circ}$ (Note ${ }^{\circ}$ that ${ }^{\circ}$ the ${ }^{\circ}$ series distributions are not of a Gaussian nature but mimic this ${ }^{\circ}$ distribution, ${ }^{\circ}$ see $^{\circ}$ reference $[18]^{\circ}$ for ${ }^{\circ}$ details.)

Many series have been identified by FT-ICR measurements ${ }^{\circ}$ and $^{\circ}{ }^{\circ}$ some $^{\circ}$ of $^{\circ}$ these $e^{\circ}$ are $^{\circ}$ collected $^{\circ}$ in $^{\circ}$ Table $^{\circ} 2$. All series have a general formula of $\mathrm{C}_{\mathrm{x}} \mathrm{H}_{\mathrm{y}} \mathrm{N}_{\mathrm{z}}$ and show similar distributions. Some general trends have been observed: (1) the degree of unsaturation increases with increasing molecular mass, (2) the degree of unsaturation is better determined by the number of nitrogens than carbons, and (3) as molecular weight increases the contribution of formulas having greater nitrogen composition increases leading to an average $\mathrm{C} / \mathrm{N}$ ratio which ${ }^{\circ}$ decreases $^{\circ}$ with $^{\circ}$ molecular $^{\circ}$ weight ${ }^{\circ}[18]$.

\section{Exposure to Air and Water}

The general formulae of $\mathrm{C}_{x} \mathrm{H}_{\mathrm{y}} \mathrm{N}_{\mathrm{z}}$ determined by ESI FT-ICR measurements indicate reaction products generated between methane and nitrogen under the anaerobic conditions is described in the Experimental section. They also imply that the samples have not been exposed long enough to air and water during isolation and analysis to form reaction products with them. The lack of ions containing oxygen for samples prepared right after harvest from the tholin reaction chamber justifies the use of ESI for these analyses, even though the samples are exposed to solvents (methanol and acetonitrile), and to air (during the droplet formation, as well as during the solvent evaporation). This is illustrated ${ }^{\circ}$ in ${ }^{\circ}$ Figure $^{\circ} 3 \mathrm{a},{ }^{\circ}$ which ${ }^{\circ}$ shows $^{\circ} a^{\circ}$ representative ${ }^{\circ} \mathrm{m} / \mathrm{z}$ region (192.0-192.3) of a "fresh" sample of the ESI spectrum which was obtained within ca. an hour after its collection from the reaction chamber (MeOH:ACN 1:1 solvent). The two main ions observed in this range are $\mathrm{C}_{11} \mathrm{H}_{18} \mathrm{~N}_{5}$ (192.1249) and $\mathrm{C}_{11} \mathrm{H}_{18} \mathrm{~N}_{3}$ (192.1501). Note that the ion at $\mathrm{m} / \mathrm{z} 192.1330$ corresponds to the ${ }^{13} \mathrm{C}$ isotope peak of the ion $\mathrm{C}_{10} \mathrm{H}_{15} \mathrm{~N}_{4}$ (191.1297).

Some control experiments have been carried out in which the samples were intentionally exposed to air and / ${ }^{\circ}{ }^{\circ}$ water. ${ }^{\circ}$ Figure $3 b^{\circ}{ }^{\circ}$ hows ${ }^{\circ} a^{\circ}$ FT-ICR ${ }^{\circ}$ spectrum ${ }^{\circ}$ of ${ }^{\circ} a$ tholin sample that was kept in a sample vial for six weeks after brief exposure to air. (Note that the solution in $\mathrm{MeOH}: \mathrm{ACN}$ was prepared just before spraying.) The comparison ${ }^{\circ}$ of $^{\circ}$ Figure $^{\circ} 3 b^{\circ}$ with $^{\circ}$ Figure $^{\circ} 3 a^{\circ}{ }^{\circ}$ clearly ${ }^{\circ}$ shows the appearance of additional peaks (although with low intensity). These peaks correspond to ions containing oxygen(s), such as $\mathrm{C}_{10} \mathrm{H}_{14} \mathrm{~N}_{3} \mathrm{O}$ (192.1137). This ion can be assigned as a water adduct of $\mathrm{C}_{10} \mathrm{H}_{12} \mathrm{~N}_{3}$ (174.1031, Series $^{\circ} 4^{\circ}$ in $^{\circ}$ Table $^{\circ} 2$. $^{\circ}$ The $^{\circ}$ ions $^{\circ}$ containing $^{\circ}$ oxygen $^{\circ}$ are observed to only contain one oxygen and correspond to simple water addition reactions with possible subsequent cleavage to hydrolytic products. For example, imine hydrolysis would be expected to be facile under these conditions and would lead to simpler cleavage products containing a single oxygen.

These hydrolysis products are becoming more prominent when the tholin samples are intentionally exposed to ${ }^{\circ}$ water. This ${ }^{\circ}$ is $s^{i}$ llustrated ${ }^{\circ}{ }^{\circ}{ }^{\circ}$ the ${ }^{\circ}$ spectrum ${ }^{\circ}$ of ${ }^{\circ}$ Figure $3 \mathrm{C}$ that was obtained for a tholin sample dissolved in $\mathrm{H}_{2} \mathrm{O}$ and heated to $100{ }^{\circ} \mathrm{C}$ for $1 \mathrm{~h}$ (Sample B in Experimental). Note that these oxygen-containing ions are even more

Table 2. Series of neutral species corresponding to lower $\mathrm{m} / \mathrm{z}$ ions detected by FT-ICR exact mass measurements

$\begin{array}{lll}\text { Series 1: } \mathrm{C}_{6} \mathrm{H}_{8}\left(\mathrm{CH}_{2}\right)_{n} \mathrm{~N}_{3} & n=0-9 & {[4]^{\mathrm{a}}} \\ \text { Series 1A: } \mathrm{C}_{6} \mathrm{H}_{10}\left(\mathrm{CH}_{2}\right)_{n} \mathrm{~N}_{3} & n=0-7 & {[3]} \\ \text { Series 1B: } \mathrm{C}_{6} \mathrm{H}_{12}\left(\mathrm{CH}_{2}\right)_{n} \mathrm{~N}_{3} & n=0-4 & {[2]} \\ \text { Series 2: } \mathrm{C}_{5} \mathrm{H}_{7}\left(\mathrm{CH}_{2}\right)_{n} \mathrm{~N}_{4} & n=0-10 & {[4]} \\ \text { Series 2A: } \mathrm{C}_{5} \mathrm{H}_{9}\left(\mathrm{CH}_{2}\right)_{n} \mathrm{~N}_{4} & n=0-5 & {[3]} \\ \text { Series 2B: } \mathrm{C}_{5} \mathrm{H}_{11}\left(\mathrm{CH}_{2}\right)_{n} \mathrm{~N}_{4} & n=0-4 & {[2]} \\ \text { Series 3: } \mathrm{C}_{4} \mathrm{H}_{8}\left(\mathrm{CH}_{2}\right)_{n} \mathrm{~N}_{5} & n=0-5 & {[3]} \\ \text { Series 3A: } \mathrm{C}_{5} \mathrm{H}_{12}\left(\mathrm{CH}_{2}\right)_{n} \mathrm{~N}_{5} & n=0-2 & {[2]} \\ \text { Series 4: } \mathrm{C}_{7} \mathrm{H}_{6}\left(\mathrm{CH}_{2}\right)_{n} \mathrm{~N}_{3} & n=0-7 & {[6]} \\ \text { Series 4A: } \mathrm{C}_{7} \mathrm{H}_{8}\left(\mathrm{CH}_{2}\right)_{n} \mathrm{~N}_{3} & n=0-9 & {[5]} \\ \text { Series 4B }=\mathrm{Series} & & \\ \text { Series 5: } \mathrm{C}_{6} \mathrm{H}_{5}\left(\mathrm{CH}_{2}\right)_{n} \mathrm{~N}_{4} & n=0-11 & {[6]} \\ \text { Series 5A: } \mathrm{C}_{6} \mathrm{H}_{7}\left(\mathrm{CH}_{2}\right)_{n} \mathrm{~N}_{4} & n=0-9 & {[5]} \\ \text { Series 5B }=\mathrm{Series} & & \\ \text { Series 6: } \mathrm{C}_{8} \mathrm{H}_{9}\left(\mathrm{CH}_{2}\right)_{n} \mathrm{~N}_{2} & n=0-4 & {[5]} \\ \text { Series 6A: } \mathrm{C}_{8} \mathrm{H}_{11}\left(\mathrm{CH}_{2}\right)_{n} \mathrm{~N}_{2} & n=0-4 & {[4]} \\ \text { Series 6B: } \mathrm{C}_{8} \mathrm{H}_{13}\left(\mathrm{CH}_{2}\right)_{n} \mathrm{~N}_{2} & n=0-3 & {[3]}\end{array}$

aThe degree of unsaturation is shown in square brackets. 

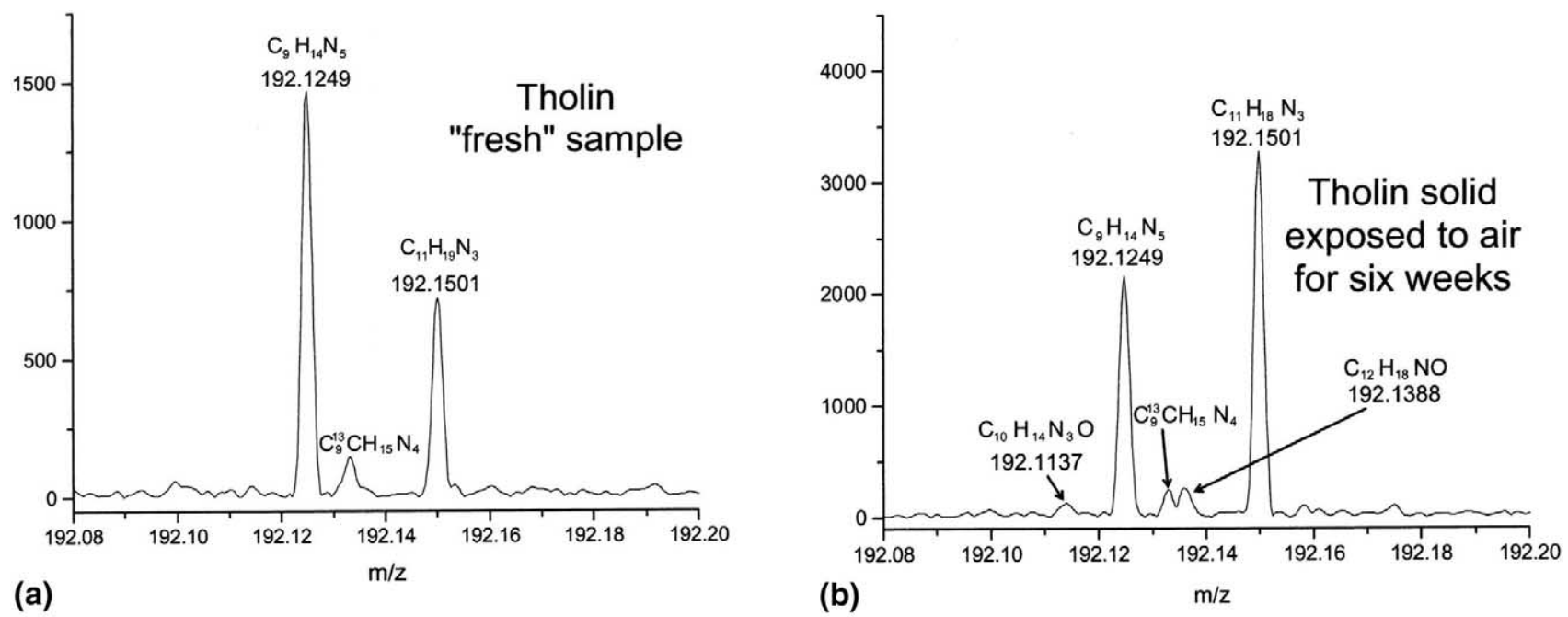

(a)

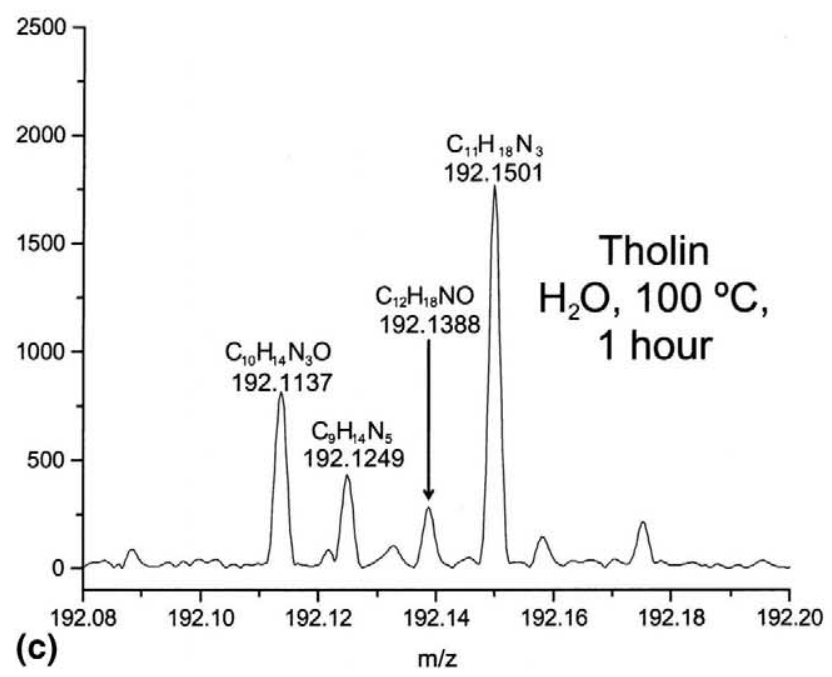

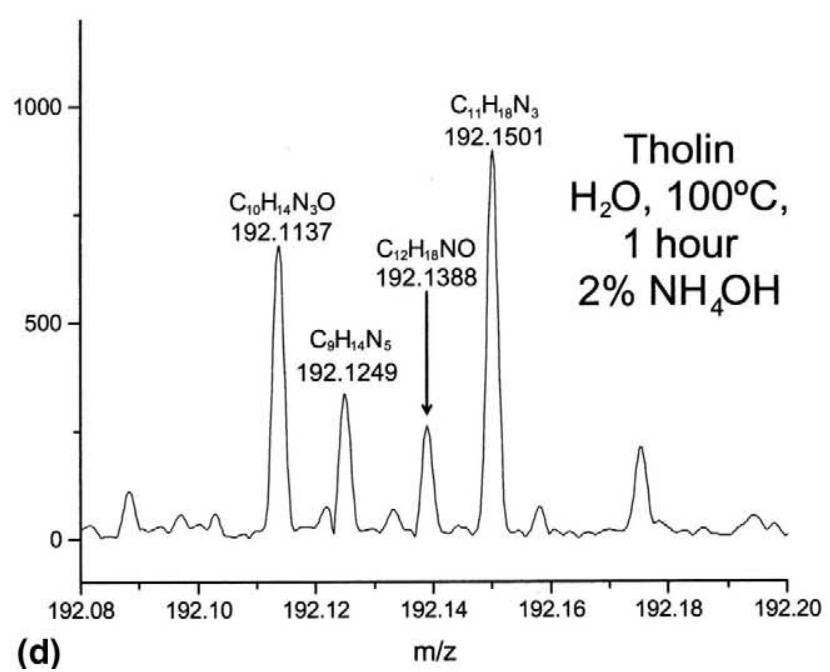

Figure 3. Effect of sample preparation and exposure to air and water on tholin ESI spectra: ions with nominal $\mathrm{m} / \mathrm{z}$ of 192 detected for (a) a neat tholin sample that was dissolved in MeOH:ACN 1:1 immediately follows harvest from the reaction chamber; (b) a neat tholin sample kept in an Eppendorf vial for six weeks and dissolved immediately before spraying; (c) a tholin sample exposed to $\mathrm{H}_{2} \mathrm{O}$ at $100{ }^{\circ} \mathrm{C}$ for one h prior to ESI sample preparation; and (d) a tholin sample hydrolyzed with $\mathrm{H}_{2} \mathrm{O}$ containing 1 to $2 \%$ of $\mathrm{NH}_{4} \mathrm{OH}$ at $100{ }^{\circ} \mathrm{C}$ for one h prior to ESI sample preparation (Sample D in the Experimental section).

intense when the hydrolysis is carried out with a small amount of $\mathrm{NH}_{4} \mathrm{OH}^{\circ}$ (Sample ${ }^{\circ}$, ${ }^{\circ}$ Figure $3 \mathrm{~d}$ ). ${ }^{\circ}$ On the ${ }^{\circ}$ other hand, these ions are clearly present when the tholin samples are dissolved in water and kept at room temperature for a few hours (not shown, but the intensities ${ }^{\circ}$ are between $^{\circ}$ those ${ }^{\circ}$ shown ${ }^{\circ}{ }^{\circ}{ }^{\circ}$ Figure $^{\circ} 3 b^{\circ}$ and $^{\circ} \mathrm{C}$ ). The oxygen-containing ions have been observed throughout the whole spectrum and are characteristic of water exposure.

It is interesting to note here that, at least in this lower mass region, we found no evidence for intense ions containing two oxygen atoms that would indicate a potential presence of carboxylic acid. It is well known that harsh hydrolysis of similar samples reveals a product mixture containing both natural and meteoritic amino ${ }^{\circ}$ acids, presumably 9 rom nitrile hydrolysis 926,27$]$. The hydrolysis of the $\mathrm{C}_{\mathrm{x}} \mathrm{H}_{\mathrm{y}} \mathrm{N}_{\mathrm{z}}$ containing tholin samples is currently further explored in a more systematic way and the results of this study will be summarized in a separate paper.

\section{H/D Exchange Measurements}

An attempt was made to carry out $H / D$ exchange in the gas phase for several $\mathrm{C}_{\mathrm{x}} \mathrm{H}_{\mathrm{y}} \mathrm{N}_{\mathrm{z}}$ ions in both the ion trap and FT-ICR cell. We have observed no significant exchange in the ion trap instrument within $10 \mathrm{~s}$ and at a source $\left(\mathrm{D}_{2} \mathrm{O}\right)$ pressure of ca. 1 to $2 \times 10^{-5}$ torr (greater than $10^{3}$ collisions). Similarly, no exchange was observed in the FT-ICR cell within $600 \mathrm{~s}$ and using $\mathrm{D}_{2} \mathrm{O}$ at two different pressures: $4.5 \times 10^{-9}$ torr and $3.7 \times 10^{-8}$ torr. In solution phase, however, rapid $\mathrm{H} / \mathrm{D}$ exchange was ${ }^{\circ}$ observed ${ }^{\circ}$ or $^{\circ}$ several ${ }^{\circ}$ ions ${ }^{\circ}$ (see, ${ }^{\circ}$ e.g., ${ }^{\circ}$ Figure $4 a^{\circ}$ and $\mathrm{b}$, for illustration). The maximum number of $\mathrm{H} / \mathrm{D}$ ex- 


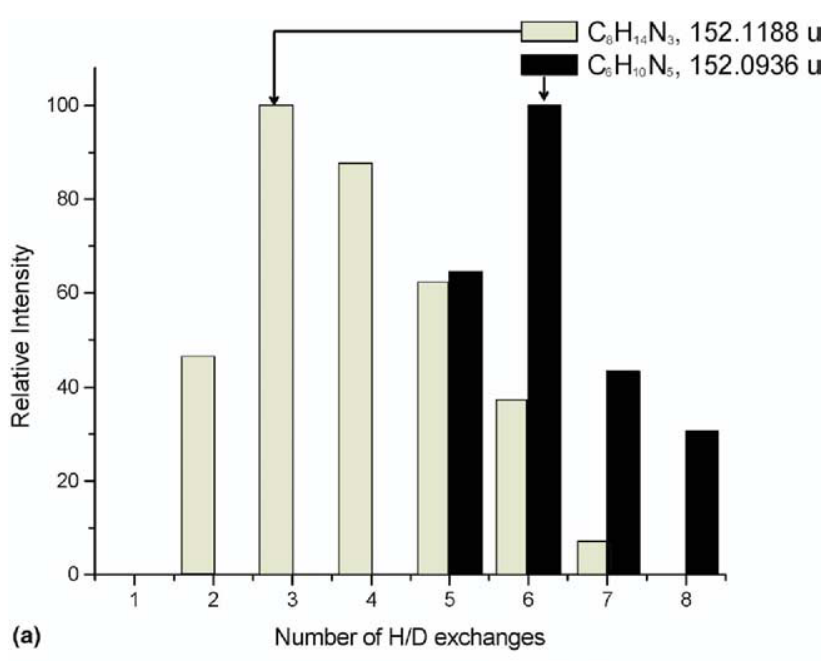

(a)

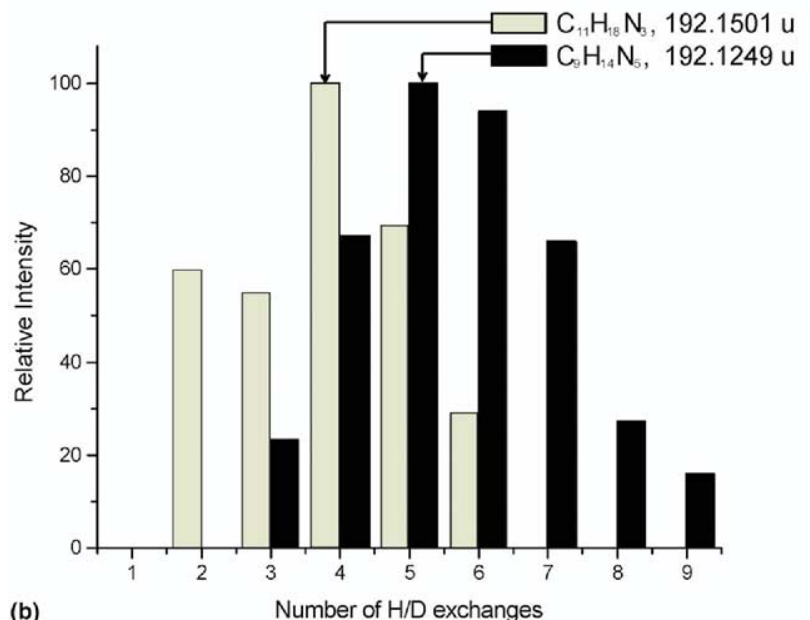

Figure 4. Representative results for solution phase H/D exchange experiments on tholin. Relative intensities as a function of $\mathrm{H} / \mathrm{D}$ exchanges for tholin unlabeled ions with nominal masses of (a) $m / z 152$ and (b) $m / z 192$.

changes and the degree of unsaturation allow us to predict some structural features of these ions. For example, for the ion with a formula of $\mathrm{C}_{8} \mathrm{H}_{14} \mathrm{~N}_{3}$ (152.1188, 'grey histograms in Figure $4 a)^{\circ}$ wefound seven to be the maximum exchangeable hydrogens. Note that one of the exchangeable hydrogen atoms is, presumably, the "ionizing" proton, so the maximum number of $\mathrm{H} / \mathrm{D}$ exchange does not necessarily indicate the maximum exchangeable hydrogen atoms in the neutral molecules. This implies that there are six exchangeable hydrogen atoms in the neutral molecules of $\mathrm{C}_{8} \mathrm{H}_{13} \mathrm{~N}_{3}$ (or at least in one of its isomeric components). These hydrogens could be partitioned in three $-\mathrm{NH}_{2}$ groups. For another ion with a larger number of nitrogen atoms, $\mathrm{C}_{6} \mathrm{H}_{10} \mathrm{~N}_{5}$ (152.0936), we observed greater number (eight) of maximum H/D exchanges (black histograms in Figure 4 a). ${ }^{\circ}$ Again, ${ }^{\circ}$ with ${ }^{\circ}$ an ionizing proton taken into account, one can partition seven hydrogens in three amino groups and one imino. The remaining nitrogen can then be in a nitrile group. Obviously, several other structural isomers can be generated and considered, especially if we consider that a variety of $H / D$ exchanges occur. The trend of increasing number in $\mathrm{H} / \mathrm{D}$ exchanges with increasing number of nitrogen atoms is further'supported by ${ }^{\text {Othe }}$ results ${ }^{\circ}$ hown in Figure $4 \mathrm{~b}$ : the maximum numbers of $\mathrm{H} / \mathrm{D}$ exchanges are six and nine for the ions $\mathrm{C}_{11} \mathrm{H}_{18} \mathrm{~N}_{3}$ (192.1501) and $\mathrm{C}_{9} \mathrm{H}_{14} \mathrm{~N}_{5}$ (192.1249), respectively. (For the MS/MS experiments carried out to check the deuterium content of the ammonia loss, see below.)

The solution phase H/D exchange measurements provide further support of the chemical and structural complexity of the tholin polymer. Not only do we have two to three species with the same nominal mass but ions with the same chemical formula may have several structural isomers. To further explore structural characteristics of these lower $\mathrm{m} / \mathrm{z}$ species, we carried out MS/MS measurements on both the IT and FT-ICR instruments, some characteristic results of which are discussed below.

\section{MS/MS Measurements}

Several ions have been selected and used as precursor ions in MS/MS experiments in the mass range of 86-300 u. For illustration, we show a few characteristic MS/MS spectra obtained on both the ion trap and FT-ICR ${ }^{\circ}$ instruments. ${ }^{\circ}$ Figure $^{\circ} 5 \mathrm{a},{ }^{\circ} \mathrm{b},{ }^{\circ}$ and ${ }^{\circ} \mathrm{c}^{\circ}$ show ${ }^{\circ}$ the MS/MS spectra of $m / z$ 87, $m / z$ 152, and $m / z 192$ obtained on the ion trap instrument. Note that although the precursor ions were selected monoisotopically, they do not necessarily represent a "pure" ion with only one chemical and structural composition [see, e.g., MS/MS results $^{\circ}$ shown $^{\circ}$ in $^{\circ}$ Figure $^{\circ} 5 \mathrm{~b}^{\circ}$ for ${ }^{\circ} \mathrm{m} / \mathrm{z}$ 152, ${ }^{\circ}$ which $^{\circ}$ is ${ }^{\circ}$ the "mixture" of two ions, $\mathrm{C}_{8} \mathrm{H}_{14} \mathrm{~N}_{3}\left(\begin{array}{ll}\mathbf{1} & 152.1188\end{array}\right)$ and $\mathrm{C}_{6} \mathrm{H}_{10} \mathrm{~N}_{5}$ (2 152.0936)].

The ${ }^{\circ} \mathrm{MS} / \mathrm{MS}^{\circ}$ spectrum $^{\circ}$ of $^{\circ} \mathrm{m} / z 7^{\circ}$ (Figure ${ }^{\circ}$ a) ${ }^{\circ}$ obtained on the ion trap instrument shows two significant fragment ions at $m / z 70$ and 56 that can be related to the loss of $\mathrm{NH}_{3}$ and $\mathrm{CH}_{3} \mathrm{NH}_{2}$, respectively. Both suggest the presence of $-\mathrm{NH}_{2}$ functionality. Because the MW of the corresponding neutral molecule is 86 , this species more likely contains two nitrogen atoms from which a chemical formula of $\mathrm{C}_{4} \mathrm{H}_{10} \mathrm{~N}_{2}$ can be suggested. The degree of unsaturation is one in this molecule. Therefore, a possible structural isomer could be $\mathrm{NH}_{2} \mathrm{CH}_{2} \mathrm{CH}=\mathrm{CH}$ $\mathrm{CH}_{2} \mathrm{NH}_{2}$. H/D exchange in the liquid phase resulted in ions of $m / z$ 87-92 $\mathbf{u}$, which indicates that the maximum number of $H / D$ exchange for $m / z 87$ is 5 (spectrum not shown). (Note that there is also a peak at $m / z 88$ in the spectra of nondeuterated tholin but this does not affect the conclusion above.) When the ion at $m / z 89$ is selected in the liquid phase $H / D$ exchange experiment, fragments at $m / z 70,57$, and 56 are detected (spectrum not shown). They can correspond to the loss of $\mathrm{ND}_{2} \mathrm{H}$, $\mathrm{CH}_{3} \mathrm{NDH}$, and $\mathrm{CH}_{3} \mathrm{ND}_{2} \mathrm{H}$, respectively. These results support the suggested structure above, although another isomer, such as $\mathrm{CH}_{2}=\mathrm{CH}-\mathrm{NH}-\mathrm{CH}_{2} \mathrm{CH}_{2} \mathrm{NH}_{2}$ can also be present.

Although not shown here, it is worth mentioning 

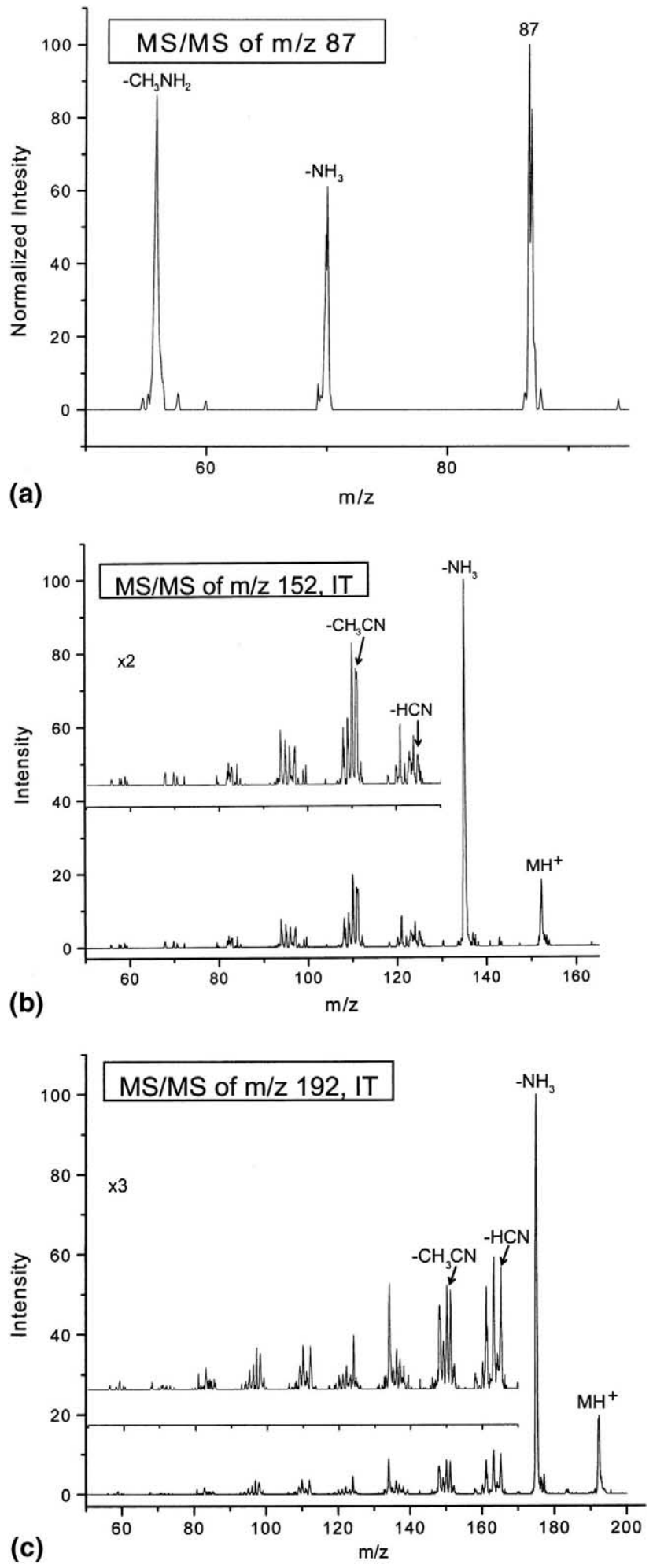

Figure 5. Ion trap MS/MS spectra obtained for tholin precursor ions of (a) $m / z$ 87, (b) $m / z$ 152, and (c) $m / z 192$.

that the MS/MS spectrum of $\mathrm{m} / \mathrm{z} 100$ shows major fragments at $m / z 83,71$, and 59 . These fragments can be the results of the loss of $\mathrm{NH}_{3}, \mathrm{CH}_{2}=\mathrm{NH}\left(\right.$ or $\left.\mathrm{C}_{2} \mathrm{H}_{5}\right)$, and $\mathrm{CH}_{3} \mathrm{CN}$, respectively. This fragmentation pattern sup- ports the presence of amino, imino, and nitrile functionalities.

As expected, the MS/MS spectrum of $m / z 152$ is more complex, ${ }^{\circ}$ showing ${ }^{\circ}$ several $^{\circ}$ fragment $^{\circ}$ ions $^{\circ}\left(\right.$ Figure $^{\circ} 5 \mathrm{~b}$ ). However, the main fragment corresponds to the loss of ammonia. Other losses of $\mathrm{HCN}\left(\mathrm{m} / z\right.$ 125) and $\mathrm{CH}_{3} \mathrm{CN}$ $(m / z 111)$ are also observed.

The MS/MS spectrum of $\mathrm{m} / \mathrm{z} 192$ also contains a lot of $^{\circ}$ fragment ${ }^{\circ}$ ions $^{\circ}\left(\right.$ Figure $\left.^{\circ} 5 \mathrm{c}\right){ }^{\circ}{ }^{\circ}$ The $^{\circ}$ losses $^{\circ}$ of $^{\circ} \mathrm{NH}_{3}(\mathrm{~m} / \mathrm{z}$ 175), $\mathrm{CH}_{2}=\mathrm{NH}(\mathrm{m} / \mathrm{z} 163), \mathrm{CH}_{3} \mathrm{NH}_{2}(\mathrm{~m} / \mathrm{z} 161)$, and $\mathrm{CH}_{3} \mathrm{CN}(\mathrm{m} / \mathrm{z} 151)$ are observed but other losses, such as the loss of $\mathrm{CH}_{3}\left(\mathrm{~m} / \mathrm{z}\right.$ 177), $\mathrm{HCN}(\mathrm{m} / \mathrm{z} 165), \mathrm{CH}_{3} \mathrm{CH}=\mathrm{NH}$ $(\mathrm{m} / \mathrm{z} 149)$ can also be suggested. The loss of the methyl radical is particularly interesting from an even-electron protonated precursor species. Note that methyl radical loss has been observed for other ions, such as $\mathrm{m} / \mathrm{z} 193$, 194 , and 195 in the ion trap but it is missing for some other ions, such as $m / z 139,140,141$, and 142 (spectra not shown). The $\mathrm{MS}^{3}$ spectrum of $m / z$ 175, i.e., of the $\left(\mathrm{MH}-\mathrm{NH}_{3}\right)^{+}$shows additional losses of $\mathrm{NH}_{3}(\mathrm{~m} / \mathrm{z}$ 158), $\mathrm{HCN}(\mathrm{m} / z \mathrm{148})$, and $\mathrm{CH}_{3} \mathrm{CN}(\mathrm{m} / z$ 134) which is, again, in agreement with amino and nitrile functionalities $^{\circ}$ (Figure $^{\circ}$ ). .

The assignments proposed based on the MS/MS experiments in the ion trap were further supported by accurate mass measurements in the FT-ICR SORI spectra. Ultrahigh resolution FT-ICR MS/MS (SORI) spectra that give further insight to the fragmentation pattern of some $^{\circ}$ selected $^{\circ}$ ions $^{\circ}$ are $^{\circ}$ shown $^{\circ}$ in $^{\circ}$ Figure $^{\circ} 7 \mathrm{a},{ }^{\circ}{ }^{\circ},{ }^{\circ}$ and ${ }^{\circ} \mathrm{c}$. Again, a primary goal of this work is to define better the functional group inventory in complex tholins. MS/MS fragmentation spectra such as these provide valuable data for this inventory but as yet are insufficiently complete to allow derivation of structures. A few characteristic fragmentation schemes are shown in Schemes 1 and 2. These MS/MS spectra were obtained for the ions with nominal mass of $152\left[1 \mathrm{C}_{8} \mathrm{H}_{14} \mathrm{~N}_{3}(152.1188 \mathrm{u})\right.$

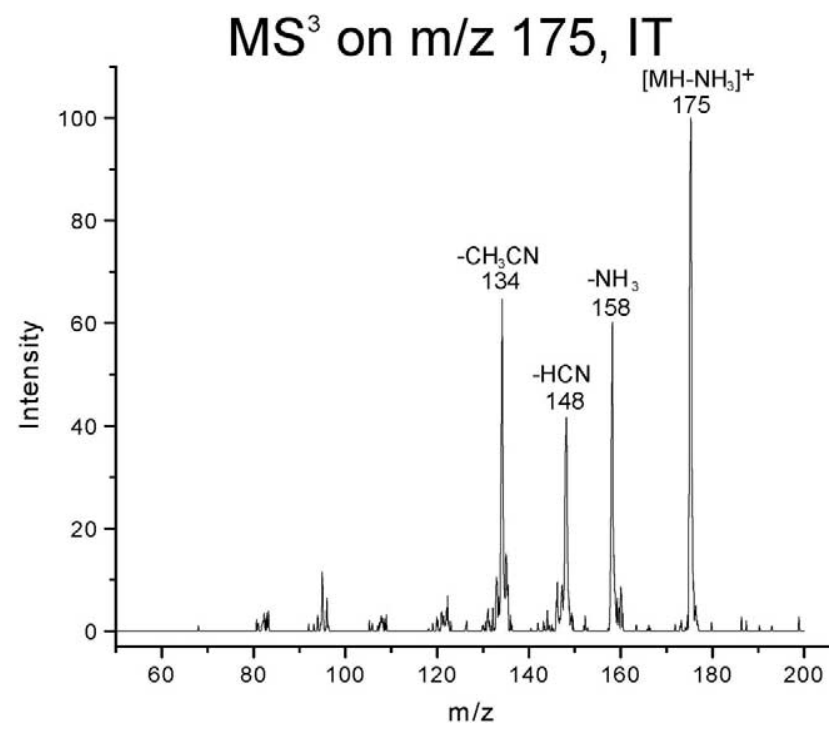

Figure 6. $\mathrm{MS}^{3}$ spectrum of the $\left[\mathrm{MH}-\mathrm{NH}_{3}\right]^{+}$ion $(\mathrm{m} / \mathrm{z}$ 175) originated from ions at nominal mass of $\mathrm{m} / \mathrm{z} 192$. 
and $\left.2 \mathrm{C}_{6} \mathrm{H}_{10} \mathrm{~N}_{5^{\circ}}\left(152.0936^{\circ} \mathrm{u}\right)\right]^{\circ}$ (Figure ${ }^{\circ} \mathrm{a}^{\circ}$ and ${ }^{\circ}$ Scheme $\left.{ }^{\circ} \mathbf{1}\right)$, their ${ }^{\circ} d 3^{\circ}$ deuterated ${ }^{\circ}$ derivatives $^{\circ}$ (Figure $\% \mathrm{~b}$ ), ${ }^{\circ}$ and ${ }^{\circ}$ for ${ }^{\circ}$ ions with nominal mass of $\mathrm{m} / \mathrm{z} 192$ detected for a tholin sample exposed to a one hour hydrolysis with $\mathrm{NH}_{4} \mathrm{OH}$ at ${ }^{\circ} 100^{\circ}{ }^{\circ} \mathrm{C}^{\circ}$ (Figure $\left.{ }^{\circ} 7 \mathrm{c}\right){ }^{\circ}$ Although ${ }^{\circ}$ the $e^{\circ}$ theoretical ${ }^{\circ}$ and

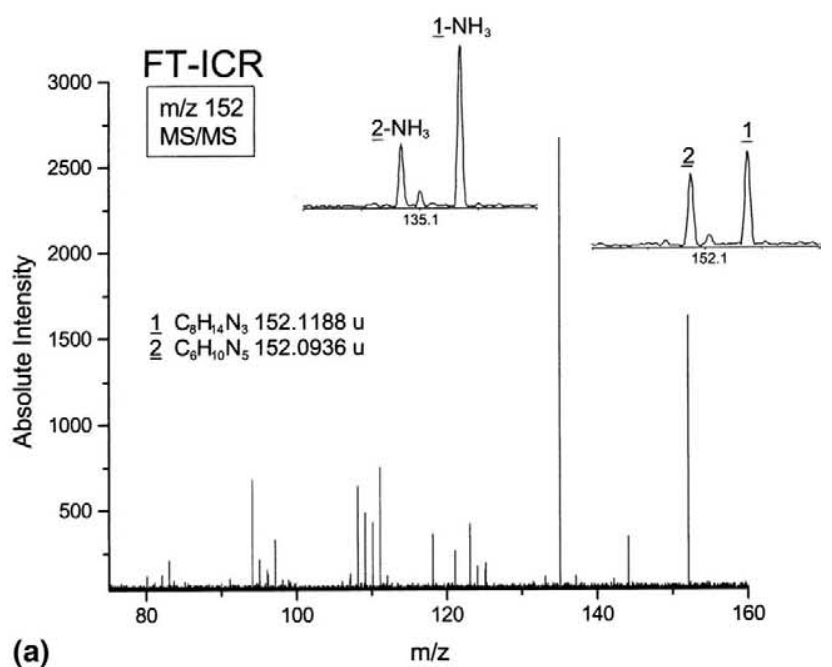

(a)

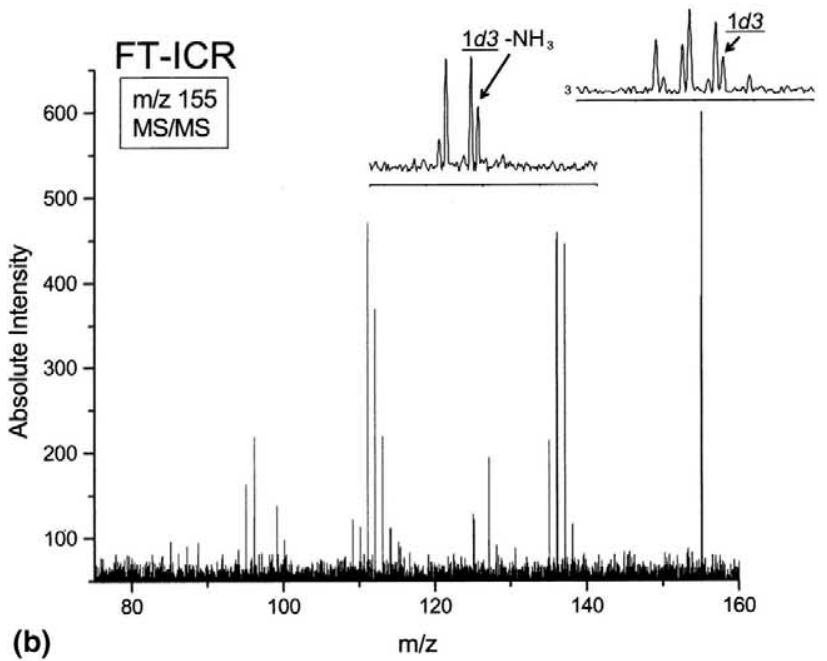

(b)

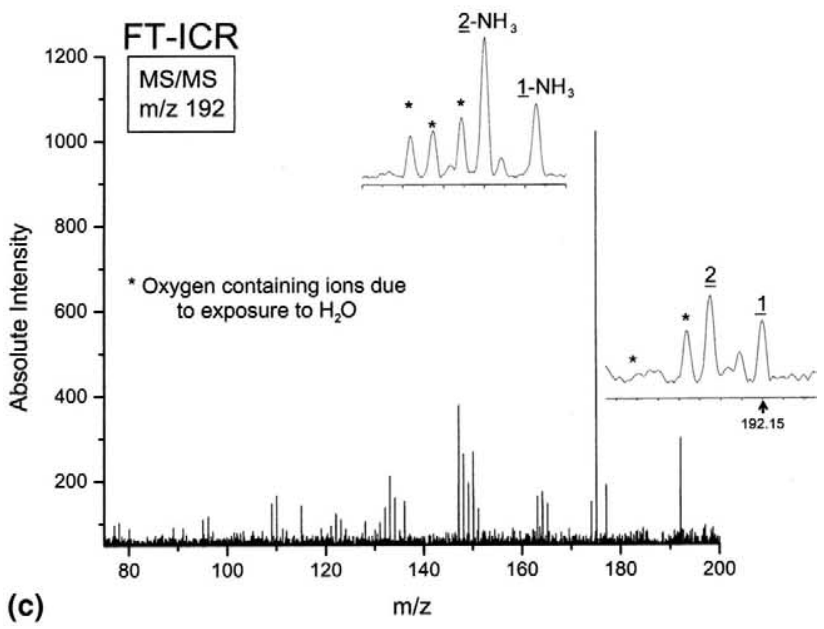

measured masses are not shown for clarity in Schemes 1 and 2 the agreement between them is less than 1 millimass unit after internal calibration on one of the precursor ions (e.g., by using $1 \mathrm{C}_{8} \mathrm{H}_{14} \mathrm{~N}_{3}$ (152.1188) as an internal standard).

Schemes 1 and ${ }^{\circ} 2$ and ${ }^{\circ}$ Figure $\% a^{\circ}$ show ${ }^{\circ}$ the ${ }^{\circ}$ fragmentation of ions which originate from "fresh" samples, i.e., those that have not been exposed to air/water (no oxygen-containing ions are observed). Scheme 2 shows the characteristic fragmentation pattern of ions with nominal ${ }^{\circ}$ mass ${ }^{\circ}$ of ${ }^{\circ} \mathrm{m} / \mathrm{z}$ 192. ${ }^{\circ}$ It $^{\circ}$ is $^{\circ}$ clear $^{\circ}$ from ${ }^{\circ}{ }^{\circ}$ igure $\% a^{\circ}$ that the pattern for the ions related to the loss of ammonia $(\mathrm{m} / \mathrm{z} 135)$ is similar to that of the precursor ions. The loss of $\mathrm{NH}_{3}, \mathrm{NH}_{2} \mathrm{D}, \mathrm{NHD}_{2}$, and $\mathrm{ND}_{3}$ is detectable for the $\mathrm{d}_{3}$ derivative for 1 , although the ions corresponding to the losses of $\mathrm{NH}_{3}{ }^{\circ}$ and ${ }^{\circ} \mathrm{ND}_{3^{\circ}}$ are $^{\circ}$ weak $^{\circ}$ (Figure ${ }^{\circ} 7 \mathrm{~b}$ ). ${ }^{\circ}$ This ${ }^{\circ}$ is ${ }^{\circ}$ in agreement ${ }^{\circ}$ with $^{\circ}$ the ${ }^{\circ}$ partial $^{\circ}$ deuteration $^{\circ}$ of 1 (see ${ }^{\circ}$ Figure 4a). ${ }^{\circ}$ As ${ }^{\circ}$ hown in 'Scheme 1, the fragmentation pattern of the ion $\mathbf{1}$ is quite complex. Besides the loss of $\mathrm{NH}_{3}$, other fragmentation pathways include the loss of $\mathrm{CH}_{3}, \mathrm{HCN}$, $\mathrm{C}_{2} \mathrm{H}_{4}, \mathrm{CH}_{2}=\mathrm{NH}, \mathrm{CH}_{3} \mathrm{NH}_{2}, \mathrm{CH}_{3} \mathrm{CN}, \mathrm{CH}_{2} \mathrm{~N}_{2}$, and $\mathrm{C}_{2} \mathrm{H}_{5} \mathrm{~N}$. It is interesting to note that a fragment ion at $\mathrm{m} / \mathrm{z} 80$ with a chemical formula of $\mathrm{C}_{5} \mathrm{H}_{6} \mathrm{~N}$ is also detected, which could be assigned as protonated pyridine. This is consistent with the pyrolysis GC-MS results that show several ${ }^{\circ}$ pyridine ${ }^{\circ}$ and ${ }^{\circ}$ pyrrole ${ }^{\circ}$ derivatives ${ }^{\circ}[28],{ }^{\circ} a^{\circ}{ }^{\circ}$ well ${ }^{\circ}$ as recent $^{\circ}{ }^{\circ}$ infrared ${ }^{\circ}$ and $^{\circ} \mathrm{UV}^{\circ}$ absorption $^{\circ}$ work $^{\circ}\left[29,{ }^{\circ} 30\right]^{\circ}$ and fluorescence ${ }^{\circ}$ studies ${ }^{\circ}[19],{ }^{\circ}$ which ${ }^{\circ}$ seem $^{\circ}$ to ${ }^{\circ}$ indicate ${ }^{\circ}$ aromatic constituents. But it needs to be stated that our accurate mass measurements and MS/MS spectra support aliphatic polyaminonitriles as a main constituent of tholin. This is consistent with the low mass $(<100 \mathrm{Da})$ GC/MS studies of Coll et al. which identify primarily aliphatic material where nitrogen is identified only in nitrile ${ }^{\circ}$ functionality ${ }^{\circ}[31]$.

The ${ }^{\circ} \mathrm{MS} / \mathrm{MS}^{\circ}$ spectra ${ }^{\circ}$ obtained ${ }^{\circ}$ for ${ }^{\circ} \mathrm{a}^{\circ}$ hydrolysis ${ }^{\circ}$ product $^{\circ}$ (Figure ${ }^{\circ} 7 \mathrm{c}^{\circ}$ for ${ }^{\circ}$ ions ${ }^{\circ}$ with $^{\circ}$ nominal $^{\circ}$ mass $^{\circ}$ of ${ }^{\circ} \mathrm{m} / \mathrm{z}$ 192) allowed us to prove the loss of $\mathrm{H}_{2} \mathrm{O}$, which suggests the addition of water to a $\mathrm{C}=\mathrm{C}$ or $\mathrm{C}=\mathrm{N}$ double bond or other reactive centers such as aziridine or isocyanide functionality. (This is also supported by the fact that ammonia loss is always observed from these O-containing ions suggesting weak or incomplete hydrolysis of only the most reactive centers under our mild hydrolysis conditions). In agreement with the results for H/D exchange experiments, this observation also supports the great chemical and structural complexity of the compounds in tholin samples, i.e., that several structural isomers may exist for isobaric ions.

Figure 7. FT-ICR SORI spectra obtained for tholin precursor ions of (a) $\mathrm{m} / \mathrm{z} 152$ from a freshly harvested and dissolved $\left(\mathrm{CH}_{3} \mathrm{OH}\right)$ sample, (b) $m / z 155\left(\mathrm{~m} / \mathrm{z} 152-d_{3}\right)$ of the same sample but dissolved in $\mathrm{CD}_{3} \mathrm{OD}: \mathrm{ACN}$ 1:1 (solution phase H/D exchange), and (c) $\mathrm{m} / \mathrm{z}$ 192 from a tholin sample exposed to $\mathrm{H}_{2} \mathrm{O}$ (containing 1 to $2 \%$ of $\mathrm{NH}_{4} \mathrm{OH}$ ) at $100{ }^{\circ} \mathrm{C}$ for one $\mathrm{h}$ (Sample D in Experimental). 


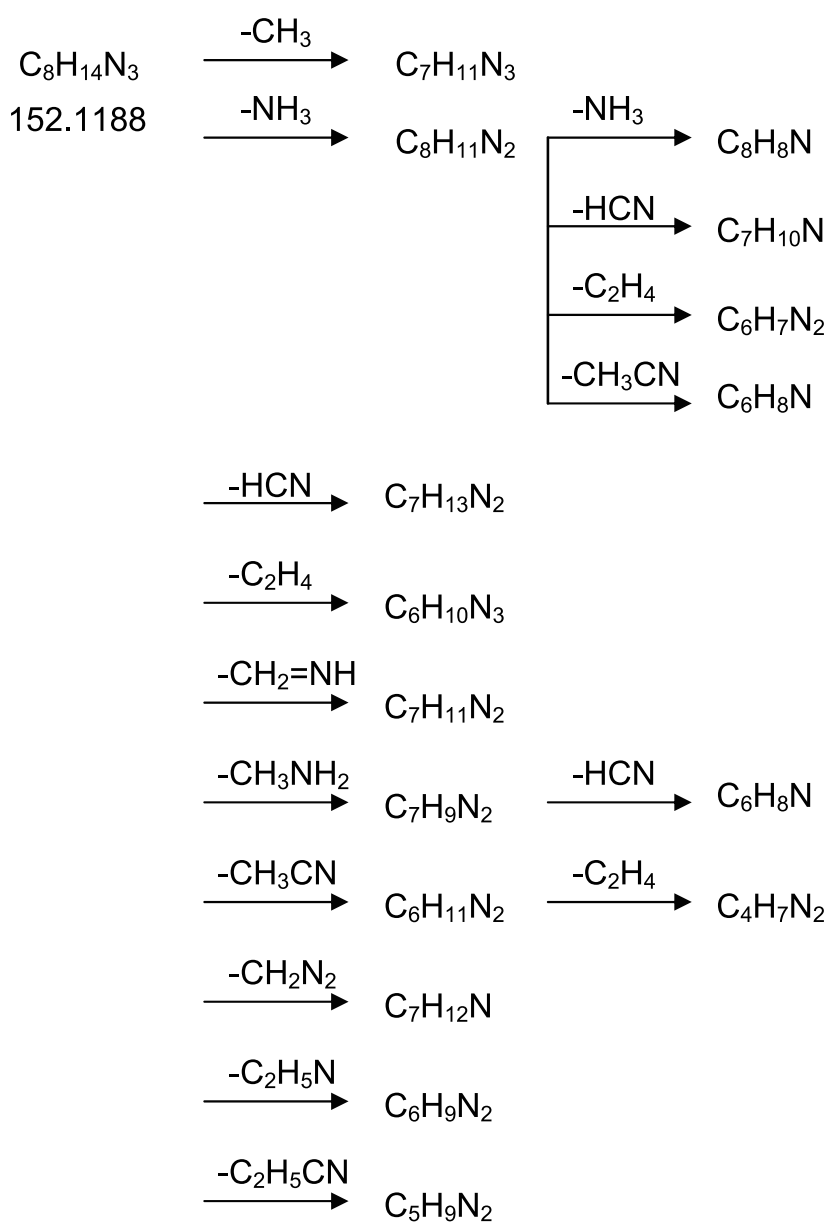

Scheme 1. Main fragmentation pathways of the ion $\mathrm{C}_{8} \mathrm{H}_{14} \mathrm{~N}_{3}{ }^{+}$.

\section{Conclusions}

The results presented here provide further information on the chemical composition and structure of compounds and structural motifs present in tholin samples. It has been shown that ultrahigh resolution (FT-ICR) mass spectrometry with accurate mass measurements can play a unique role to reveal the complexity and wide variety of compounds in tholin samples. These measurements unambiguously demonstrate that tholin consists largely of polymeric sets of compounds with $\mathrm{C}_{x} \mathrm{H}_{\mathrm{y}} \mathrm{N}_{\mathrm{z}}$ chemical composition. The general trend is that the number of nitrogens increases with increasing molecular mass and the degree of unsaturation increases primarily with the number of nitrogens. Although it is difficult to unambiguously derive detailed structures from the H/D exchange and tandem MS/MS measurements carried out in the ion trap and FT-ICR cell, the results presented here provide strong support for the presence of amino, imine, and nitrile functionalities in the wide variety of species in tholin samples.

The present work outlines the utility of electrospray ionization to ionize the compounds in tholin samples in an "inert" way, i.e., this ionization method does not result in "oxygen" contamination in freshly harvested and prepared samples. However, when the samples are intentionally exposed to water, oxygen-containing ions appear in the spectra. This unambiguously demonstrates the reactivity of $\mathrm{C}_{x} \mathrm{H}_{\mathrm{y}} \mathrm{N}_{\mathrm{z}}$ compounds towards water. Although the present study does not provide evidence for the formation of amino acid like compounds, some observations imply that these compounds can be formed via more vigorous hydrolysis. A more systematic and quantitative hydrolysis study is currently in progress in our laboratories and the results
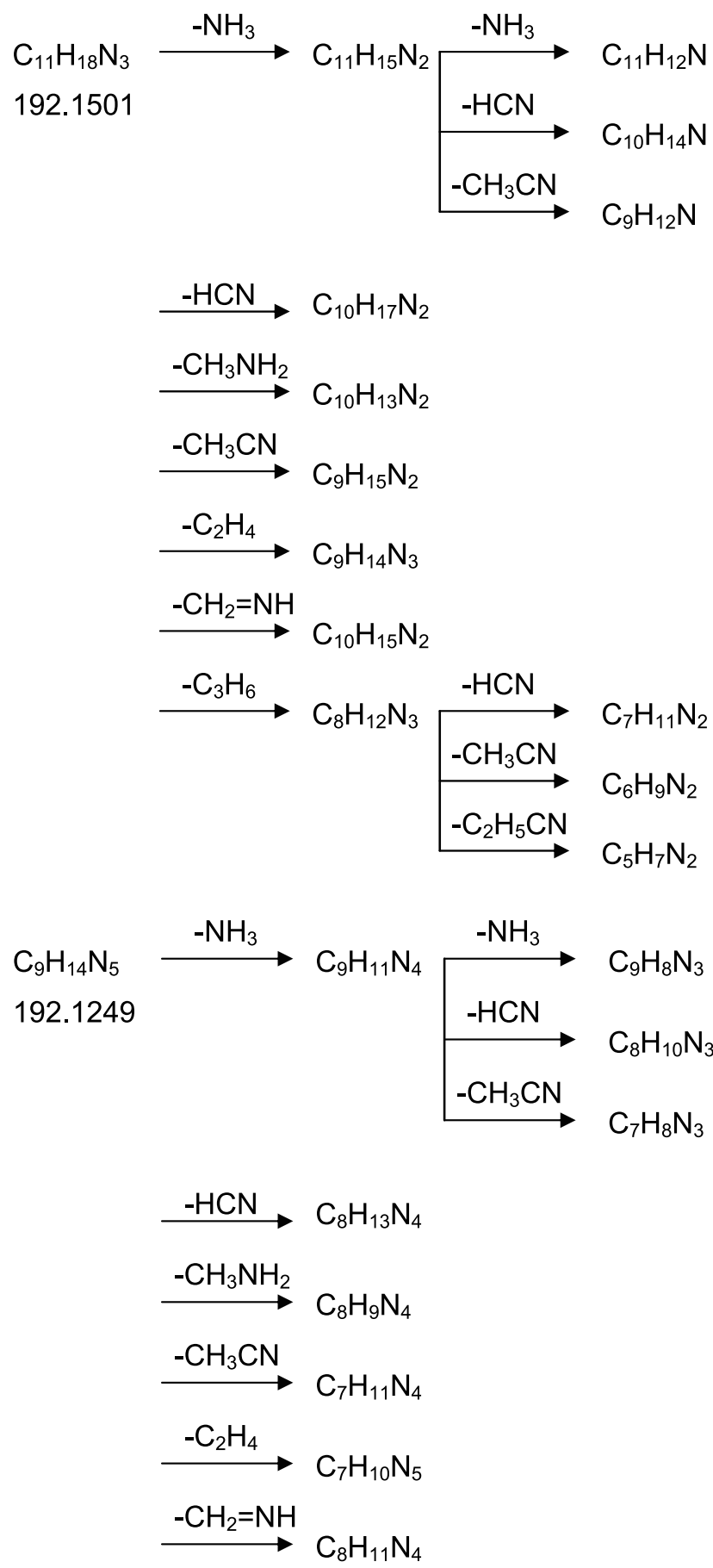

Scheme 2. Main fragmentation pathways of the ions $\mathrm{C}_{11} \mathrm{H}_{18} \mathrm{~N}_{3}{ }^{+}$ and $\mathrm{C}_{9} \mathrm{H}_{14} \mathrm{~N}_{5}{ }^{+}$. 
of these studies will be summarized in a forthcoming paper.

\section{Acknowledgments}

The authors gratefully acknowledge support of this work through the Directors Research and Development Fund, Jet Propulsion Laboratory. They acknowledge the assistance of Dr. Niladri Sarker in the preparation of some of the tholin employed in this work, and Gene McDonald, Jack Beauchamp, Robert Hodyss, and Pat Beauchamp for advice and insight regarding this work.

\section{References}

1. Hanel, R.; Conrath, B.; Flasar, F. M.; Kunde, V.; Maguire, W.; Pearl, J.; Pirraglia, J.; Samuelson, R.; Herath, L.; Allison, M.; Cruikshank, D.; Gautier, D.; Gierasch, P.; Horn, L.; Koppany, R.; Ponnamperuma, C. Infrared Observations of the Saturnian System from Voyager 1. Science 1981, 212, 192-200.

2. Hanel, R.; Conrath, B.; Flasar, F. M.; Kunde, V.; Maguire, W.; Pearl, J.; Pirraglia, J.; Samuelson, R.; Cruikshank, D.; Gautier, D.; Gierasch, P.; Horn, L.; Ponnamperuma, C. Infrared Observations of the Saturnian System from Voyager 2. Science 1982, $215,544-548$

3. Kunde, V. G.; Aikin, A. C.; Hanel, R. A.; Jennings, D. E.; Maguire, W. C.; Samuelson, R. E. $\mathrm{C}_{4} \mathrm{H}_{2}, \mathrm{HC}_{3} \mathrm{~N}$, and $\mathrm{C}_{2} \mathrm{~N}_{2}$ in Titan's Atmosphere. Nature 1981, 292, 686-688.

4. Maguire, W. C.; Hanel, R. A.; Jennings, D. E.; Kunde, V. G.; Samuelson, R. E. Nature 1981, 292, 683-686.

5. Yung, Y. L.; Allen, M.; Pinto, J. P. Photochemistry of the Atmosphere of Titan: Comparison Between Model and Observations. Astrophys. J. Suppl. 1984, 55, S465-S506.

6. Thompson, W. R.; Henry, T. J.; Schwartz, J. M.; Khare, B. N.; Sagan, C. Plasma Discharge in $\mathrm{N}_{2}+\mathrm{CH}_{4}$ at Low Pressures: Experimental Results and Applications to Titan. Icarus 1991, 90, 57-73.

7. Toublanc, D.; Parisot, J. P.; Brillet, J. Photochemical Modeling of Titan's Atmosphere. Icarus 1995, 113, 2-26.

8. Lara, L. M.; Lellouch, E.; Lopez-Moreno, J. J.; Rodrigo, R. Vertical Distribution of Titan's Atmospheric Neutral Constituents. J. Geophys. Res. 1996, 101, 23261-23283.

9. McKay, C. P.; Coustenis, A.; Samuelson, R. E.; Lemmon, M. T.; Lorenz, R. D.; Cabane, M.; Rannou, P.; Drossart, P. Physical Properties of the Organic Aerosols and Clouds on Titan. Planet. Space Sci. 2001, 49(1), 79-99.

10. Banaszkiewicz, M.; Lara, L. M.; Rodrigo, R.; López-Moreno, J. J.; Molina-Cuberos, G. J. A Coupled Model of Titan's Atmosphere and Ionosphere. Icarus 2000, 147, 386-404.

11. Israel, G.; Cabane, M.; Brun, J-F.; Niemann, H; Way, S.; Riedler, W.; Steller, M.; Raulin, F.; Coscia, D. Huygens Probe Aerosol Collector Pyrolyser Experiment. Huygens Probe Aerosol Collector Pyrolyser Experiment. Space Sci. Rev. 2002, 104, 433-468.

12. Niemann, H. B.; Atreya, S. K.; Bauer, S. J.; Biemann, K.; Block, B.; Carignan, G. R.; Donahue, T. M.; Frost, R. L.; Gautier, D.; Haberman, J. A.; Harpold, D.; Hunten, D. M.; Israel, G.; Lunine, J. L.; Mauersberger, K.; Owen, T. C.; Raulin, F.; Richards, J. E.; Way, S. H. The Gas Chromatograph Mass Spectrometer for the Huygens Probe. Space Sci. Rev. 2002, 104, 553-591.

13. Hunten, D. M.; Tomasko, M. G.; Flaser, F. M.; Samuelson, R. E.; Strobel, D. F.; Stevenson, D. J. In Saturn, Gehrels, T.; Mathews, M. S., Eds.; University of Arizona Press: Tucson, AZ, 1984; pp 671-759.
14. Smith, B. A.; Soderblom, L.; Beebe, R.; Boyce, J.; Briggs, G.; Bunker, A.; Collins, S. A.; Hansen, C. J.; Johnson, T. V.; Mitchell, J. L.; Terrile, R. J.; Carr, M.; Cook, A. F.; Cuzzi, J.; Pollack, J. B.; Danielson, G. E.; Ingersoll, A.; Davies, M. E.; Hunt, G. E.; Masursky, H.; Shoemaker, E.; Morrison, D.; Owen, T.; Sagan, C.; Veverka, J.; Strom, R.; Suomi, V. E. Encounter with Saturn: Voyager I Imaging Science Results. Science 1981, 212, 163-191.

15. Smith, B. A.; Soderblom, L.; Batson, R.; Bridges, P.; Inge, J.; Masursky, H.; Shoemaker, E.; Beebe, R.; Boyce, J.; Briggs, G.; Bunker, A.; Collins, S. A.; Hansen, C. J.; Johnson, T. V.; Mitchell, J. L.; Terrile, R. J.; Cook, A. F.; Cuzzi, J.; Pollack, J. B.; Danielson, G. E.; Ingersoll, A. P.; Davies, M. E.; Hunt, G. E.; Morrison, D.; Owen, T.; Sagan, C.; Veverka, J.; Strom, R.; Suomi, V. E. A New Look at the Saturn System: The Voyager II Images. Science 1982, 215, 504-537.

16. Rages, K.; Pollack, J. B. Vertical Distribution of Scattering Hazes in Titan's Upper Atmosphere. Icarus 1983, 55, 50-62.

17. Rannou, P.; Ferrari, C.; Rages, K.; Roos-Serote, M.; Cabane, M. Characterization of Aerosols in the Detached Haze Layer of Titan. Icarus 2000, 147, 267-281.

18. Sarker, N.; Somogyi, A.; Lunine, J. I.; Smith, M. A. Titan Aerosol Analogs: Analysis of the Nonvolatile Tholins. Astrobiology 2003, 3, 719-726.

19. Hodyss, R.; McDonald, G.; Sarker, N.; Smith, M. A.; Beauchamp, P. M.; Beauchamp, J. L. Fluorescence Spectra of Titan Tholins: In-Situ Detection of Astrobiologically Interesting Areas on Titan's Surface. Icarus 2004, 171, 525-530.

20. Done, M.; Mack, L. L.; Hines, R. L.; Mobley, R. C.; Ferguson, L. D.; Alice, M. B. Molecular Beams of Macroions. J. Chem. Phys. 1968, 49 (5), 2240-2249.

21. Fenn, J. B.; Mann, M.; Meng, C. K.; Wong, S. F.; Whitehouse, C. M. Electrospray Ionization for Mass Spectrometry of Large Biomolecules. Science 1989, 246, 64-71.

22. Mann, M.; Meng, C. K.; Fenn, J. B. Interpreting Mass Spectra of Multiply Charged Ions. Anal. Chem. 1989, 61, 1702-1708.

23. Smith, R. D.; Loo, J. A.; Edmonds, C. G.; Barinaga, C. J.; Udseth, H. R. Anal. Chem. 1990, 62, 882-899.

24. Smith, R. D.; Loo, J. A.; Barinaga, C. J.; Edmonds, C. G.; Udseth, H. R. Collisional Activation and Collision-Activated Dissociation of Large Multiply Charged Polypeptides and Proteins Produced by Electrospray Ionization. J. Am. Soc. Mass Spectrom. 1990, 1, 53-65.

25. Tanaka, K.; Waki, H.; Ido, Y.; Akita, S.; Yoshida, T. Protein and Polymer Analyses up to $\mathrm{m} / \mathrm{z} 100,000$ by Laser Ionization Time-of-Flight Mass Spectrometry. Rapid Commun. Mass Spectrom. 1988, 2, 151-153.

26. Khare, B. N.; Sagan, C.; Ogino, H.; Nagy, B.; Er, C.; Schram, K. H.; Arakawa, E. T. Amino Acids Derived from Titan Tholins. Icarus 1986, 68, 176-184.

27. McDonald, G. D.; Thompson, W. R.; Heinrich, M.; Dhare, B. N.; Sagan, C. Chemical Investigation of Titan and Triton Tholins. Icarus 1994, 108, 137-145.

28. Sacks,, R. Personal communication, 2004

29. Khare, B. N.; Bakes, E. L. O.; Imanaka, H.; McKay, C. P.; Cruikshank, D. P.; Arakawa, E. T. Analysis of the TimeDependent Chemical Evolution of Titan Haze Tholin. Icarus 2002, 160, 172-182.

30. Imanaka, H.; Khare, B. N.; Elsila, J. E.; Bakes, E. L. O.; McKay, C. P.; Cruikshank, D. P.; Sugita, S.; Matsui, T.; Zare, R. N. Icarus 2004, 168, 344-366.

31. Coll, P.; Coscia, D.; Smith, N.; Gazeau, M. C.; Ramirez, S. I.; Cernogora, G.; Israel, G.; Raulin, F. Experimental Laboratory Simulation of Titan's Atmosphere: Aerosols and Gas Phase. Planet. Space Sci. 1999, 47, 1331-1340. 